\title{
【論文】
}

食料品アクセス問題の実態と市町村の対応

一定量的接近と全国市町村意識調査による分析から一

農林水産政策研究所 高橋 克也・薬師寺 哲郎

\section{Difficulties in Accessing Food and their Countermeasures on Local Governments:}

Using GIS of Grid-Square Statistics and Analysis of All Municipality Consciousness

\author{
Katsuya TAKAHASHI, Tetsuro YAKUSHIJI \\ Policy Research Institute, MAFF
}

\begin{abstract}
:
Population aging and a decrease in the number of food stores affect the daily food purchase of elderly people. One of the factors burdening the elderly is the distance to stores. In this study, we estimated the population for whom distance to the nearest fresh food store is over $500 \mathrm{~m}$ in Japan. Owing to the unavailability of a reliable list of the relevant stores in Japan, we employed the gridsquare statistics of Population Census and Census of Commerce. We used the probabilities of the relevant stores being more than 500m away from residences, assuming that a store and a person are uniformly distributed in the grid and that stores are located independently of one another. We estimated that, in Japan, 44 million people and above live over 500m from the nearest fresh food store. We also analyze the actual conditions of food accessibility on the basis of the result of all municipality consciousness survey. There is growing awareness that accessing food issues, on the other hand it is delay taking action.
\end{abstract}

Keyword: Access to food, inconvenience and trouble in shopping, food desert, distance between stores and residences, grid-square Statistics, municipality consciousness

\section{1.はじめに}

現在、わが国では身近な小売店の閉店が増えて おり、全国各地で「シャッター通り」と呼ばれる 中心市街地の空洞化が目立つようになっている。 同時に、これまで地域にあった路線バス等の公共 交通機関が徐々に縮小または廃止されており、こ れら交通手段から取り残された高齢者等で、日常 的な食料品の買い物すら不便や困難な「買い物難 民」あるいは「買い物弱者」と呼ばれる問題が 顕在化しつつある $[1]$ 。経済産業省による推計
では、該当する人口は全国で 600 万人存在すると もいわれており、その速やかな解決が訴えられて いる $[2]$ 。

これらの問題は、海外では「フードデザート」 として扱われており、低所得地域における食料品 の入手困難性、なかでも栄養バランスのとれた新 鮮な食料品の摂取が難しくなるという、地域問題 や貧困問題としての側面が強調されてきた [3] [4]。わが国でも、杉田［1］による買い物難民 の調查を唂矢とし、この問題に焦点があてられる ようになった。また、岩間 [5] は、地理学から のアプローチによりわが国におけるフードデザー 
卜問題を提起し、都市部においてこの様な問題に 直面する住民が高齢者を中心に増加しつつあるこ と、その要因として社会的弱者の排除があること を指摘している。さらに、栄養学の視点からも問 題の重要性が指摘されており、政策および環境、 個人的要因から構成される食環境において、食品 選択を通じた行動が栄養状態を通じて健康に影響 を及ぼすとしている [6]。

この様な問題が発生する要因を食料品需給とい った視点から捉えれば、現在わが国の人口が減少 傾向にあるなかで高齢者人口の急激な増加があげ られる。すなわち、食料品全体の需要そのものが 徐々に縮小するなかで、需要の中核が若年層や現 役世代から高齢者へと急速に推移していることで ある。高齢者にとって、加齢による身体機能の低 下は買い物を含めた日常生活がより困難になるこ とを意味している。

同時に、供給面では、食料品を販売する小売店 の閉店の増加、特にこれまで地域に密着していた ローカルスーパーや小規模な個人商店が無くなっ ていることである。商業統計によると、食肉や鮮 魚、野菜・果実小売店を合計した生鮮小売店でみ ると、1991年には全国で116,712店あったものが、 2007年には57,345店とほぼ半減しており、小売店 が急速に減少していることが示されている。これ ら小売店が激減した理由であるが、経営者の高齢 化や後継者の不在に加えて、大規模量販店（以下、 GMS）などのショッピングセンターの新設や出 店といった要因が大きい。そのため、これまで街 の中心部や商店街にあった多数の零細小売店が、 その競争に敗れて閉店や廃業に追い込まれた。特 に、1990年の大規模小売店舗法（大店法）の大幅 緩和以降では、全国各地でGMSの郊外出店ラッ シュから中心部の空洞化が一層進行する事態が生 じている（註 $1 ） 。$

仮に、人口が減少し高齢者が増加したとしても、 住民の近隣に小売店があるならば「買い物難民」 といった問題は発生しない。しかし、GMSをは じめとする新規店舗の立地は自動車利用を前提に 広範な商圈を設定しており、その意味ではむしろ 店舗立地がこれまでの住民の居住とほとんど無関 係に進められてきたといえる。その結果、住民と
店舗立地の隔離が進行し、自動車を利用しない住 民において食料品需給の空間的なミスマッチが発 生したのである（註 2 ）。

以下、本稿では、この様な住民の日常的な食料 品の買い物に不便や苦労がある状況を「食料品ア クセス問題」として定義する。なぜなら、これら 問題の起点は住民と店舗の近接性にあり、住民の 食料品へのアクセスが決定的に重要な要因となる からである。しかし、これまで食料品アクセス問 題の発生地域や規模や範囲といった問題の全体像 はもとより、発生原因や具体的な対策といった実 態は必ずしも明らかにされてこなかった。

この様な問題意識から、著者らは食料品アクセ ス問題へのアプローチとして、(1)住民と店舗の空 間条件の定量的推計、(2)問題の発生現場としての 市町村の実態と対応状況、(3)問題の当事者として の住民意識の解明、を課題としており、本稿では (1)及び(2)を明らかにする $[7][8][9][10]$ 。

その手順として、はじめに各種統計データと GIS（地理情報システム）を組み合わせた分析に より、該当する人口や地域を特定して食料品アク セス問題の全体像を可視化する。次に、実際に食 料品アクセス問題が発生している現場において、 すなわち市町村といった基礎自治体における問題 認識とそこでの取り組みや対策を全国的な意識調 査から探る。さらに、定量及び定性的指標を組み 合わせた包括的な分析によって、食料品アクセス 問題を規定する地域の条件と市町村が重視する対 策の関連を明らかにする。最後に、分析結果から 得られた示唆と実際の取り組み事例を通じて、食 料品アクセス問題の解決に必要な視点について提 起する。

\section{2. 定量的接近による食料品アクセス問題}

一般に、徒歩による買い物は片道で $500 \mathrm{~m}$ 以内、 すなわち往復 $1 \mathrm{~km}$ の範囲内とされている（註 3 ）。 そこで、本稿では日常の買い物に不便や苦労を感 じる住民を店舗から往復 $1 \mathrm{~km}$ 以上に居住する人 口と仮定した。また、食料品アクセス問題のフー ドデザートの側面も考慮して、店舗として生鮮食 料品を扱う小売店（生鮮食料品販売店舗）を対象 
とした（註 4$)$ 。以下、本稿では国勢調査及び商 業統計のメッシュデータを用いて、居住地から生 鮮食料品販売店舗までの直線距離が $500 \mathrm{~m}$ 以上離 れている人口を推計した（註 5 )。

推計方法を大まかに示すと、人口の存在するメ ッシュ(居住メッシュ) から最も近い店舗がある メッシュまで $500 \mathrm{~m}$ 以上離れている確率を求める。 すなわち、この確率はある地点から最も近い店舗 までどの程度離れているかを示す割合であり、確 率が高いことは店舗までの距離が相対的に遠いこ とを意味している（註 6 ）。求められた確率に各 メッシュの人口を乗じることで最終的な人口の推 計が可能となる。

推計結果をメッシュ単位で表示したものが図 1 である。濃淡に関わらず全てのメッシュは何れも 人口が存在しており、空白は山間部や県境など人 が住んでいない部分である。ここで、色の薄い店 舗まで $500 \mathrm{~m}$ 以上の人口割合が $40 \%$ 未満のメッシ 工、すなわち徒歩での買い物が便利な地域は、大 都市や店舗周辺といった一部に偏っていることが 示されている。一方で、人口割合が75\%以上の色 の濃いメッシュ、つまり相対的に買い物環境が不 便な地域であるが、これらに該当する地域は地方 のみならず大都市周辺部にも拡がっていることが わかる。また、中京地区の拡大図でみられるよう に、都市の中心や近郊でも人口割合の高い地域が 存在するなど、スプロール化した特徵もみられる。 なお、これら人口割合が $75 \%$ 以上のメッシュは、

日本全体の居住メッシュの 8 割弱を占めることが 確認されている（註 7 )。

各メッシュを市町村単位に集計・統合したもの が図 2 である。ここでも買い物環境に恵まれてい る市町村は、県庁所在地や都市部などの一部に限 られており、買い物が不便な地域が県境や山間部 の市町村に偏在していることがわかる。京阪神地 区でみれば、買い物環境に恵まれた地域は交通条 件の良い大都市部や沿岸部となっていることが示 されている。

これら推計結果に、各メッシュの人口を乗じて 日本全体で集約したものが表 1 である。生鮮食料 品販売店舗まで $500 \mathrm{~m}$ 以上ある人口、すなわち買 い物に不便や苦労を感じているとされる人口は全
国で4,676万人存在しており、全人口の $36.6 \%$ に相

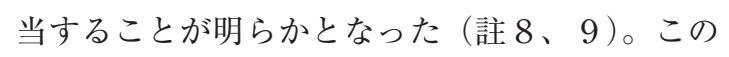
うち、65歳以上の高齢者人口は 1,017 万人で全高 齢者の $39.6 \%$ 占めるが、この割合からも高齢者 が店舗までの距離が遠くなる傾向にあることがわ かる。地域区分でみても、これらに該当する人口 の割合は地方圈が高く、地方圈で食料品アクセス 問題が深刻化している状況が予想される。

また、食料品の買い物に不便や苦労がある人の 多くが自動車を運転できない状況にあることを考 慮すると、これらに相当する人口は全国で856万 人 $(6.7 \%)$ おり 65 歳以上の高齢者に限定する と 335 万人 $(13.0 \%)$ と推計された（註10)。ここ でも、移動手段のそしい高齢者が食料品アクセス 問題のしわ寄せを受けている状況がうかがえる。

ここで、店舗まで $500 \mathrm{~m}$ 以上の人口割合別に市 町村と人口を示したものが表 2 である。人口割合 が40\%未満の市町村は、全国で333市町村で全人 口の $58.4 \%$ 占めているのに対し、人口割合が75 \%以上の市町村は399市町村で全人口の $3.4 \%$ に過 ぎない。ま、各人口割合別の平均、すなわち人 口に占める店舗まで $500 \mathrm{~m}$ 以上人口は、 $40 \%$ 未満 の市町村が $22.0 \% 、 40 ７ 5 \%$ の市町村では $54.8 \%$ 、 $75 \%$ 以上の市町村では $82.1 \%$ あ゙った。一方で、 店舗まで $500 \mathrm{~m}$ 以上人口に占める65歳以上の割合 は、同人口割合が高い市町村ほど高いことから、 これら地域では高齢者ほど買い物に不便や苦労を 感じる状況におかれていることが指摘できる。

\section{3. 市町村からみた食料品アクセス問題}

わが国の食料品アクセス問題の全体像について、 各種統計データとGISから一定の基準の下によっ て定量的に推計されることが示された。それでは、 実際にこれら食料品の買い物に不便な住民を抱え る自治体では、どの様な問題認識や対応が採られ ているのか。いわば、食料品アクセス問題の定性 的な特徵について、現場の市町村の実態を明らか にする。

このため、2010年 7 ～月の期間において東京 特別区を含んだ全国1,750の全自治体（2010年 3 月末時点）を対象に紙面による意識調査を行った。 

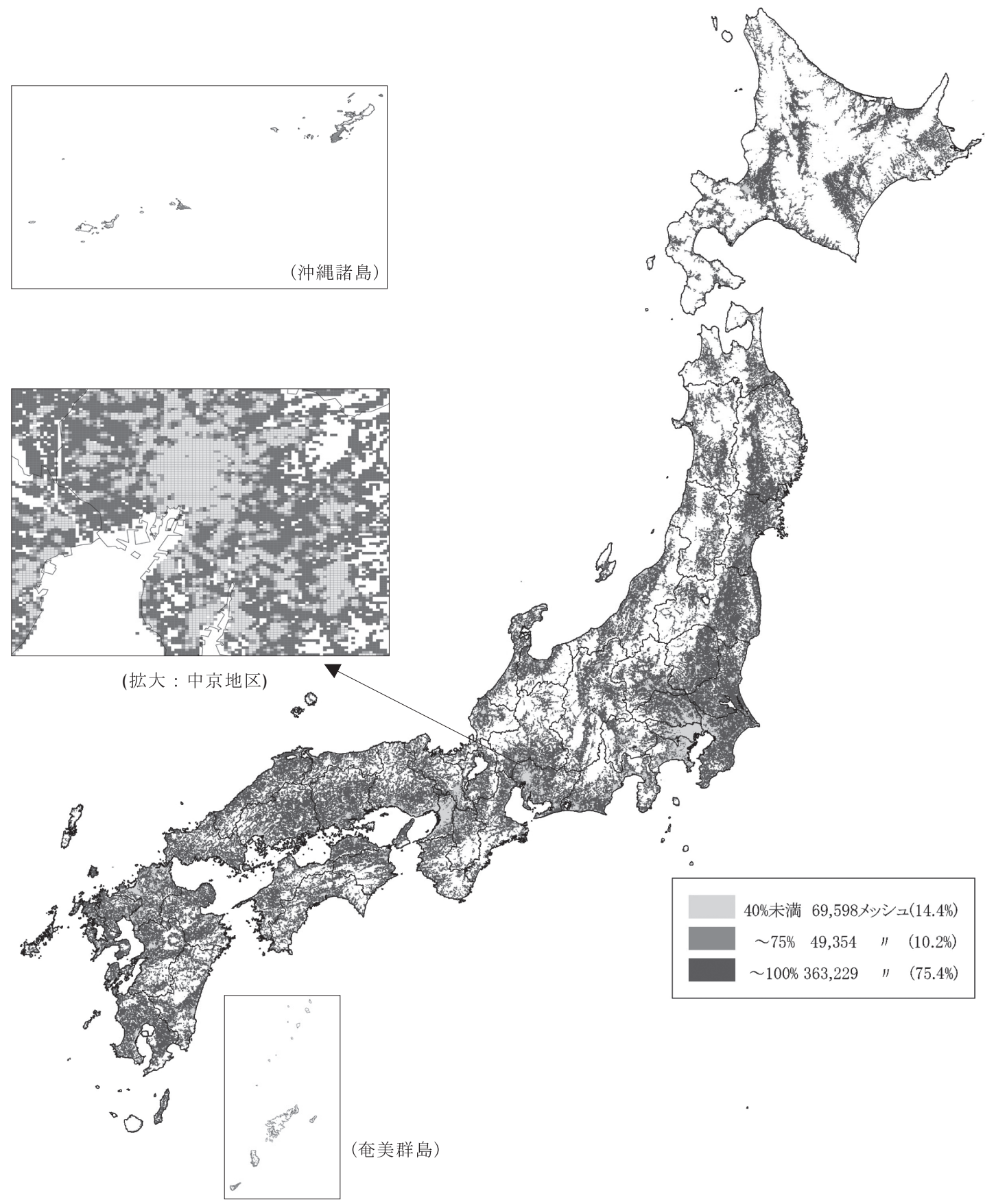

図 1 店舗まで500m以上の人口割合（メッシュ別）

資料：筆者ら推計による。 

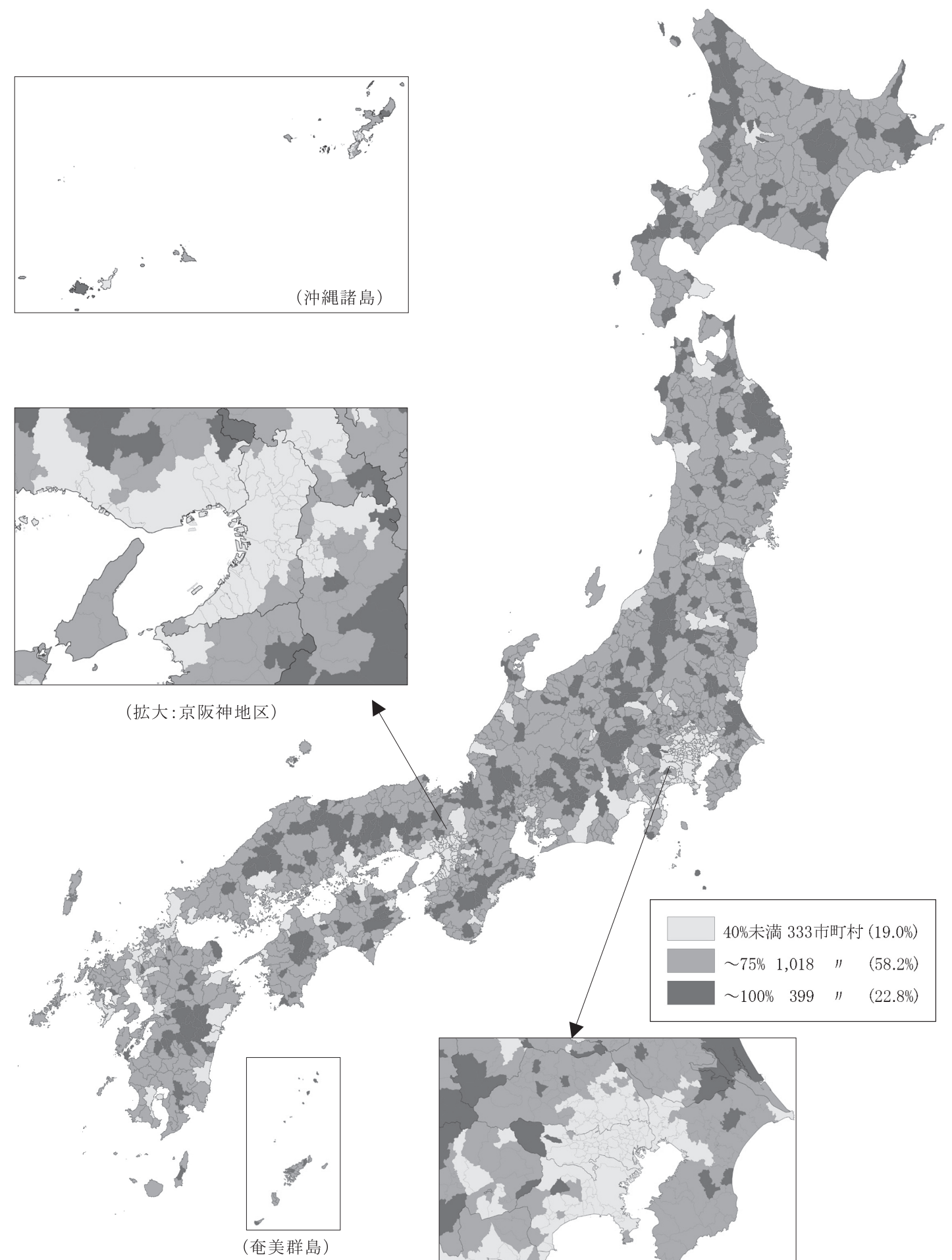
食料品アクセス問題の実態と市町村の対応

表 1 店舗まで $500 m$ 以上の人口

\begin{tabular}{|c|c|c|c|c|c|c|}
\hline \multirow[b]{2}{*}{ 人口 } & \multicolumn{2}{|c|}{ 全国計 } & \multicolumn{2}{|c|}{ うち三大都市圈 } & \multicolumn{2}{|c|}{ うち地方圈 } \\
\hline & 4,676 & 36.6 & 1,719 & 26.8 & 2,957 & 46.5 \\
\hline うち65歳以上 & 1,017 & 39.6 & 320 & 27.5 & 697 & 49.7 \\
\hline 自動車を持たない人口 & 856 & 6.7 & 390 & 6.1 & 466 & 7.3 \\
\hline うち65歳以上 & 335 & 13.0 & 133 & 11.4 & 202 & 14.4 \\
\hline
\end{tabular}

資料：筆者ら推計による。

註：1）三大都市圈とは、埼玉、千葉、東京、神奈川、愛知、三重、岐皁、大阪、京都、兵庫、奈良である。

2 ）割合とは、地域区分の総人口、または65歳以上人口に対する割合である。

表 2 店舗まで $500 \mathrm{~m}$ 以上の人口割合別市町村

\begin{tabular}{|c|c|c|c|c|c|c|c|c|}
\hline \multirow[b]{2}{*}{ 市町村数 } & \multicolumn{2}{|c|}{$\begin{array}{l}\text { 合計 } \\
\text { (割合) }\end{array}$} & \multicolumn{2}{|c|}{$\begin{array}{r}40 \% \text { 未満 } \\
\text { (割合) }\end{array}$} & \multicolumn{2}{|c|}{$\begin{array}{r}40 \sim 75 \% \\
\text { (割合) }\end{array}$} & \multicolumn{2}{|c|}{$\begin{array}{l}75 \% \text { 以上 } \\
\text { (割合) }\end{array}$} \\
\hline & 1,750 & 100.0 & 333 & 19.0 & 1,018 & 58.2 & 399 & 22.8 \\
\hline 人口 (a) & 12,777 & 100.0 & 7,462 & 58.4 & 4,879 & 38.2 & 435 & 3.4 \\
\hline うち店舗まで500m以上（b) & 4,676 & 100.0 & 1,643 & 35.1 & 2,676 & 57.2 & 357 & 7.6 \\
\hline " うち65歳以上（c) & 1,017 & 100.0 & 307 & 30.2 & 612 & 60.2 & 98 & 9.6 \\
\hline 店舗まで500m以上割合（b/a） & \multicolumn{2}{|c|}{36.6} & \multicolumn{2}{|c|}{22.0} & \multicolumn{2}{|c|}{54.8} & \multicolumn{2}{|c|}{82.1} \\
\hline " うち65歳以上割合 $(\mathrm{c} / \mathrm{b})$ & \multicolumn{2}{|c|}{21.7} & \multicolumn{2}{|c|}{18.7} & \multicolumn{2}{|c|}{22.9} & \multicolumn{2}{|c|}{27.4} \\
\hline
\end{tabular}

資料：筆者ら推計による。

表 3 対策の必要性・直接的対策の実施状況

(単位：件、\%)

\begin{tabular}{lrrr}
\hline & $\begin{array}{c}\text { 全国計 } \\
(1,118)\end{array}$ & $\begin{array}{c}\text { うち三都市圈 } \\
(341)\end{array}$ & $\begin{array}{c}\text { うち地方圈 } \\
(777)\end{array}$ \\
\hline 対策の必要性 & 100.0 & 100.0 & 100.0 \\
\hline 1. 必要である & 28.5 & 21.8 & 31.5 \\
2. ある程度必要である & 51.7 & 53.4 & 50.9 \\
3. あまり必要でない & 14.8 & 16.5 & 14.0 \\
4. 必要でない & 5.0 & 8.3 & 3.6 \\
\hline 直接的対策の実施 & 100.0 & 100.0 & 100.0 \\
\hline 1. 実施している & 24.3 & 19.5 & 26.5 \\
2. 実施を検討している & 10.1 & 9.8 & 10.3 \\
3. 実施していない & 65.5 & 70.7 & 63.2 \\
\hline
\end{tabular}

資料：農林水産政策研究所 $[7]$ 。

註：1）地域区分は表 1 に従う。

2) カッコ内は回答数である。

調查の結果、最終的に1,118件の回答が得られ、 回収率は $64 \%$ となった。
1 ）対策の必要性と直接的対策の実施状況

表 3 より、食料品の買い物が不便な住民に対し て、何らかの対策が「必要である」とする市町村 は全体の 3 割弱を占めていることが示された。ま た「ある程度必要である」とする回答を含めれば、 全体のおよそ 8 割の市町村が対策の必要性を訴え ており、市町村において食料品アクセス問題が解 決すべき重要な政策課題として認識されているこ とが明らかとなった。

一方で、現在、具体的に何らかの直接的な対策 を実施しているかについては、回答全体の 2 割程 度であった。今後対策が期待される「実施を検討 している」を含めても全体の 4 割弱であり、問題 認識が進んでいる反面で実際の対応が大きく遅れ ている実態が示されている（註11）。ここでも、 対策の必要性や直接的対策の実施状況の割合は何 れも地方圈が高く、地方圈の食料品アクセス問題 に対する危機感が強く表れている。 


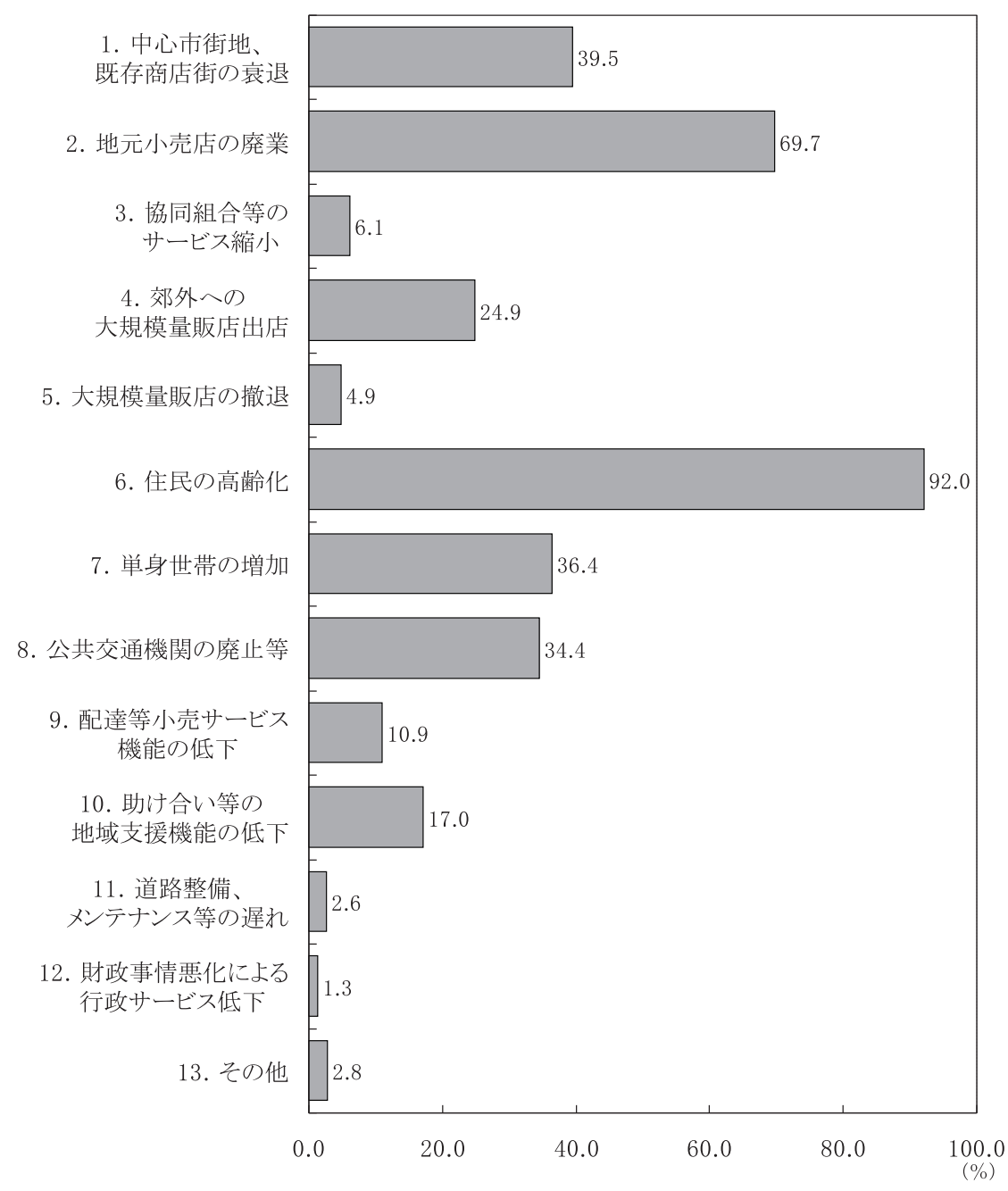

図3買い物が不便な住民が発生する理由(複数回答)

資料：農林水产政策研究所 [7]。

2 ) 問題の発生理由

市町村において食料品アクセス問題が発生する 理由は何か。図 3 に示したように、最も大きい要 因として指摘するのは「住民の高齢化」であり、 全体の 9 割がその理由としてあげている（註12）。 次いで「地元小売店の廃業」や「中心市街地・既 存商店街の衰退」といった供給側の原因も大きい。 同時に「単身世帯の増加」「公共交通機関の廃止等」 もあげられ、食料品需給とともに両者を結ぶ交通 条件の悪化が原因となっている可能性がうかがえ る。
一方で「助け合い等の地域支援機能の低下」「配 達等小売サービス機能の低下」「協同組合等のサー ビス縮小」といった項目もわずかながらあげられ ている。これら項目は、県境等の中山間部にある 市町村の多くで指摘されており、これまで地域の 拠点であった郵便局やJA支店等の統廃合が影響 を及ぼしていることがうかがえる。

この点から、食料品アクセス問題は住民の高齢 化や身近な小売店の縮小といった全国共通の要因 とともに、地域住民を支えてきた各種支援機能の 低下など、各地域の個別実態を反映した複合的な 
〈街づくり・交通対策〉

1. 中心市街地対策の実施・支援

2. 総合計画・都市マスタープランへの考慮・反映

3. 大型店・郊外型店対策

4. 路線バス等の運行・支援

〈商業振興・小売対策〉

5. 空き店舗対策の実施・支援

6. 地元商店助成・支援

7. 共同・地域店舗等の出店・運営

8. 直売所等の出店・運営

9. 移動販売車導入 $\cdot$ 運営・支援

〈地域づくり・支援対策〉

10. 地域の支援組織紹介・活動支援

11. 地域づくり等、地域活動の補助・支援

12. 高齢者・地域見守り協定等の支援 〈行政サービス〉

13. バス券等、外出支援・送迎サービス*

14. 宅配、配送サービス等の支援

15. 買い物ボランティア、代行等の紹介・支援

16. 配食サービス等の実施・支援*

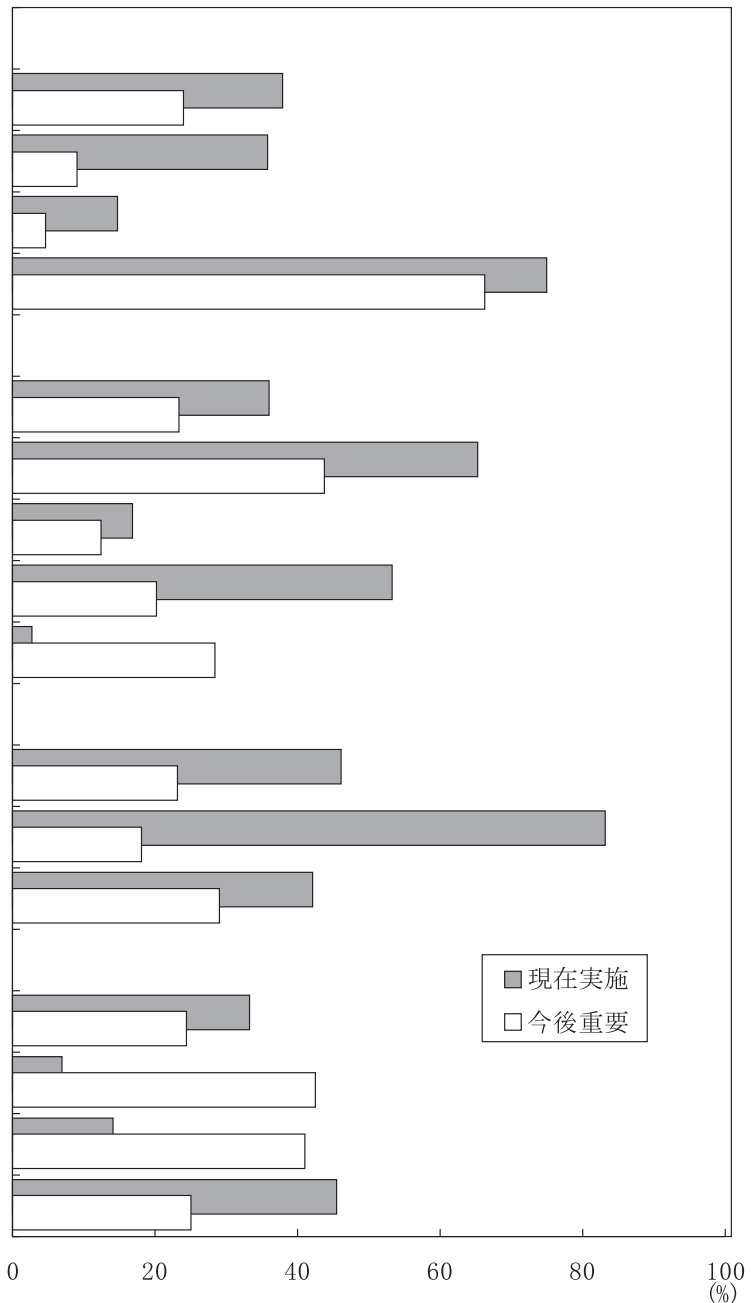

図4 買い物が不便な住民に対する対策と今後重要と考える対策 (複数回答)

資料：農林水産政策研究所 $[7]$ 。

註：*は身体障害者・介護保険等の対象を除いたものである。

原因から構成されていることが予想される。同時 に、これら発生理由は必ずしも独立した要因や事 象ではなく、例えば郊外へのGMS進出が地元小 売店や中心市街地の衰退の原因となるように、複 雑かつ相互が密接に関連していることが考えられ る。

3 ）現在実施している対策と今後重要と考える対 策

図 4 は、現在、買い物が不便な住民に実施して いる対策と今後重要と考える対策について示した。
現在の実施対策として最も多いのは「地域づくり 等、地域活動の補助・支援」であり、次いで「路 線バス等の運行 ・支援」「地元商店助成・支援」「直 売所等の出店・運営」といった対策が、全体の半 数を超える市町村で実施されている。これら対策 は、後にみるような地方バス路線維持対策や中心 市街地活性化事業といった具体的な支援策や事業 と結びつくが、何れも住民の買い物の利便性向上 をその目的としたものではなく、地域交通支援や 街づくりの一環として行われていることに留意す る必要がある。 
また「移動販売車導入・運営・支援」や「大型 店・郊外店対策」など、いわば食料品アクセス問 題で即効的となる対策の実施率は必ずしも高くな い。移動販売車の導入では、事業者への補助の公 益性とともに財政的な問題が、GMS等の大型店 の立地規制については市町村の権限外という制度 的な側面がこれら対策実施の制約になっていると みられる（註13）。

同じく、図 4 では市町村が今後重要と考える対 策として「路線バス等の運行・支援」や「地元商 店への助成・支援」等をあげられており、これら 対策は現在実施している対策としても支持されて いる。逆に「移動販売車導入」「宅配、配送サービ ス等の支援」「買い物ボランティア、代行等の紹 介・支援」等の今後重要とされながら現在実施が 遅れているものなど、対策間での一致と齟蹬がみ られるのも特徵である。先にみたように、前者の 対策は街づくりや交通など既存政策として運用さ れているのに対し、後者は県や国レベルでの政策 的支援の枠組みには組み込まれていないことが市 町村での取り組みの遅れにつながっていると考え られる。

\section{4. 市町村の特徵と食料品アクセス問題}

これまでの一連の観察から、わが国で食料品ア クセス問題に直面する人口は全人口の $1 / 3$ あまり 存在しており、相対的に不便な買い物環境にある 店舗まで $500 \mathrm{~m}$ 以上の人口割合が $75 \%$ 以上の地域 は、居住メッシュの 8 割に相当することが定量的 に示された。一方、食料品アクセス問題に対し現 場の市町村では、問題認識が高まっている反面で 実際の対策が進んでいないという実態も明らかに なった。その発生理由として、住民の高齢化や地 元小売店の廃業といった共通性とともに、支店の 廃止や配達サービスの低下など地域固有の原因か ら構成されていることも確認された。

しかし、食料品アクセス問題がどの様な条件の 下で発生し、現場である市町村の問題認識や発生 理由、あるいは具体的な対策とどう結びつくのか、 すなわち食料品アクセス問題を規定する要因や関 係性については明らかではない。これらの結びっ
きが明らかになれば、食料品アクセス問題の類型 化が可能になるとともに、市町村といった現場で の解決方法にも大きく貢献することができる。

そこで住民と店舗の空間条件、すなわち店舗ま で $500 \mathrm{~m}$ 以上の人口割合を起点に、人口規模や高齢 化の状況および単身世帯、自動車保有等の市町村 の条件とともに、発生理由と問題認識と直接的対 策の実施状況、今後重要となる対策との関連につ いて群間の検定を行った。表 3 でも示された様に、 各項目の変数は分布には大きな偏りが想定される ことからノンパラメトリック検定である KruskalWallis 検定を適用し、その後 Bonferroni 調整に よって群間の大小を確認した。以下、店舗までの 人口割合別に食料品アクセス問題の類型化を試み る(註14)。

検定結果を表 4 に示すと、店舗まで $500 \mathrm{~m}$ 以上 の人口割合が $40 \%$ 未満の市町村は、人口規模の大 きさや単身世帯比率の高さ、および高齢化比率の 低さに示されるように大都市などの都市部であり、 これら市町村の位置は先の図 2 から示されていた。 これら市町村では、食料品アクセス問題に対する 問題認識や対策実施の割合は相対的に低いものの、 発生理由として「中心・商店街の衰退」「郊外 GMS出店」「地域支援機能低下」等が他の人口割 合の地域に比べて有意に高かった。一方、食料品 アクセス問題で今後重要になる対策は「地元商 店」「空き店埔」「中心市街地」といった対策が支持 されている。

店舗までの人口割合が 40 ～75\% と中程度の市町 村は、平均で 5 万人弱の人口を抱え、これら市町 村で食料品アクセス問題に対する問題認識の割合 が最も高い。ここでの発生理由は「中心・商店街 の衰退」であり「郊外GMS出店」といった都市 部でみられた特徽も備えている。同時に「公共交 通廃止」といった地方特有の発生理由もあげてお り、これらの中には近年の市町村合併で広範な行 政区を抱える市町村があるなど、多様な市町村が 含まれているとみられる（註15）。また、今後重 要になる対策として、発生理由に対応して「中心 市街地」や「路線バス等」とともに「地域支援組 織」「宅配・配送サービス」に対する期待も高くな っている。 
食料品アクセス問題の実態と市町村の対応

表 4 人口割合別市町村による群間比較

(単位：人、\%)

\begin{tabular}{|c|c|c|c|c|c|}
\hline & & a. $40 \%$ 未満 & b. $40 \sim 75 \%$ & c. $75 \%$ 以上 & 方向 \\
\hline \multirow{4}{*}{ 条件 } & 人口* ${ }^{*}$ & 223,465 & 49,551 & 10,972 & $a>b>c$ \\
\hline & 高齢化比率* & 19.2 & 25.0 & 30.1 & $\mathrm{a}<\mathrm{b}<\mathrm{c}$ \\
\hline & 単身世帯比率* & 28.2 & 22.8 & 22.0 & $\mathrm{a}>\mathrm{b}, \mathrm{a}>\mathrm{c}$ \\
\hline & 自動車保有率* & 112.9 & 152.9 & 160.5 & $\mathrm{a}<\mathrm{b}<\mathrm{c}$ \\
\hline \multirow{2}{*}{$\begin{array}{l}\text { 問題認識 } \\
\text { 対策実施 }\end{array}$} & 対策の必要性（統合） ${ }^{*}$ & 70.9 & 83.5 & 81.7 & $\mathrm{a}<\mathrm{b}, \mathrm{a}<\mathrm{c}$ \\
\hline & 直接的対策の実施 $(\text { 統合 })^{*}$ & 18.8 & 25.1 & 28.3 & $\mathrm{a}<\mathrm{c}$ \\
\hline \multirow{12}{*}{ 発生理由 } & 1. 中心・商店街衰退* & 48.6 & 40.7 & 26.2 & $a>c, b>c$ \\
\hline & 2. 地元小売廃業 & 72.9 & 70.5 & 64.2 & \\
\hline & 3. 組合サービス縮小* & 1.2 & 6.9 & 9.6 & $\mathrm{a}<\mathrm{b}, \mathrm{a}<\mathrm{c}$ \\
\hline & 4. 郊外GMS出店* & 26.7 & 27.8 & 15.3 & $a>c, b>c$ \\
\hline & 5. GMS撤退* & 7.5 & 5.3 & 0.9 & $\mathrm{a}>\mathrm{c}, \mathrm{b}>\mathrm{c}$ \\
\hline & 6. 住民高齢化 & 89.0 & 92.8 & 93.4 & \\
\hline & 7. 単身世帯増 & 39.2 & 35.1 & 36.7 & \\
\hline & 8. 公共交通廃止 ${ }^{*}$ & 26.7 & 36.9 & 36.7 & $a<b$ \\
\hline & 9. 小売サービス低下 & 10.2 & 11.4 & 10.5 & \\
\hline & 10.地域支援機能低下* & 24.3 & 17.1 & 8.7 & $\mathrm{a}>\mathrm{b}>\mathrm{c}$ \\
\hline & 11.道路メンテ遅れ & 1.6 & 2.1 & 4.8 & \\
\hline & 12.行政サービス & 1.6 & 1.0 & 1.7 & \\
\hline \multirow{16}{*}{ 重要対策 } & 1. 中心市街地 ${ }^{*}$ & 29.6 & 25.5 & 14.5 & $\mathrm{a}>\mathrm{c}, \mathrm{b}>\mathrm{c}$ \\
\hline & 2. 総合計画・都市マス & 10.8 & 9.7 & 5.7 & \\
\hline & 3. 大型店 $\cdot$ 郊外店 ${ }^{*}$ & 6.8 & 4.8 & 1.8 & $a>b, a>c$ \\
\hline & 4. 路線バス等* & 55.6 & 70.1 & 68.0 & $\mathrm{a}<\mathrm{b}, \mathrm{a}<\mathrm{c}$ \\
\hline & 5. 空き店舗* & 34.8 & 22.0 & 14.5 & $a>b, a>c$ \\
\hline & 6. 地元商店* & 58.8 & 41.9 & 32.0 & $a>b>c$ \\
\hline & 7. 共同・地域店舗 & 15.2 & 12.0 & 10.1 & \\
\hline & 8. 直売所等 & 19.6 & 19.6 & 22.4 & \\
\hline & 9. 移動販売車 & 22.8 & 29.6 & 31.1 & \\
\hline & 10. 地域支援組織* & 34.8 & 44.6 & 46.1 & $\mathrm{a}<\mathrm{b}, \mathrm{a}<\mathrm{c}$ \\
\hline & 11. 地域づくり・活動* & 28.4 & 23.4 & 17.1 & $a>c$ \\
\hline & 12. 高齢者 · 地域見守り協定 & 21.6 & 16.3 & 18.9 & \\
\hline & 13. バス券・外出・送迎 & 28.8 & 28.3 & 30.7 & \\
\hline & 14. 宅配・配送サービス* & 14.4 & 26.2 & 30.7 & $\mathrm{a}<\mathrm{b}, \mathrm{a}<\mathrm{c}$ \\
\hline & 15. 買物ボラ・代行* & 35.6 & 41.1 & 46.9 & $\mathrm{a}<\mathrm{c}$ \\
\hline & 16. 配食サービス等 & 25.6 & 24.3 & 25.9 & \\
\hline
\end{tabular}

資料：筆者ら推計による。

註：1）発生理由は図 3、重要対策は図 4 の各項目の略である。

2）各項目の*印は KruskalWallis 検定（5\%水準）で有意なものである。

3）群間の大小は Bonferroni 調整によるものである。

人口割合が $75 \%$ 以上の市町村、すなわち相対的 に買い物環境の不便な市町村は、人口規模は小さ い反面で高い高齢化比率を持った市町村であり、 これらは主に山間部にあることは先の図 2 でみた とおりである。ここでは問題認識とともに対策実 施の割合が高いことが示されている。問題の発生 理由として「組合サービスの縮小」が有意に高い のに対し、今後重要な対策では「路線バス等」「買 物ボランティア・代行」「地域支援組織」「宅配・配 送サービス等」が有望視されている。

また、何れの市町村でも発生理由として高い割 合が示された「住民高齢化」「地元小売業廃業」「単
身世帯増」の有意性は確認されず、これらは人口 割合に関わらず食料品アクセス問題の共通する要 因であることがここでも示された。

これら結果を概説すれば、市町村のおかれた条 件と食料品アクセス問題の発生理由は整合的で、 つまり人口割合が $40 \%$ 未満の都市部では残されて いる中心部・商店街の衰退、人口割合が $40 〜 75 \%$ の市町村においてはこれらとともに公共交通の廃 止をその理由としてあげている。同時に、発生理 由と今後重要となる対策の対応関係は、何れも地 域に残存する資源や機能を活用、あるいはそれら を強化する方向で対策が選択されていることがわ 
かる。例えば、人口割合が $40 \%$ 未満の都市的な特 徵を持つ市町村では、中心部や郊外GMS出店と いった理由に対して地元商店や空き店舗対策が重 視され、逆にそれらの特徵を持たない人口割合が $75 \%$ 以上の市町村においては、唯一残された地域 支援などの役割を重視していた。また、これら市 町村の中間的な性格を持つ人口割合が $40 〜 75 \%$ の 市町村では、公共交通の廃止といった理由に対し て路線バス等の対策が重視されている。この様に、 食料品アクセス問題では地域の条件を反映した発 生理由と重視対策の関連を持つことが明らかにな った。

\section{5. 食料品アクセス問題の解決に向けて}

\section{1 ）市町村での取り組み事例}

最後に、実際に市町村で実施している対策をと りあげながら、これまでの観察と分析結果から得 られた政策的示唆を明らかにする。ここで紹介す る地方都市の事例は、市町村といった食料アクセ ス問題が発生している現場での事業や取り組みの 運用実態を示すとともに、県や国を含めた実施主 体といった視点では食料品アクセス問題の有効な 切り口となる。

福島県白河市は、県南部に位置する人口 65,707 人 (2005年国勢調査) の地方都市であり、東北の 玄関口にある城下町として知られている。小売環 境の面では、広域的には県南部の中心都市である ものの、市内ではGMS等の郊外型店舗による中 心部の空洞化がかなり進行している（註16）。

表 5 に現在、白河市で実施されている食料品ア クセス問題に関わる一連の事業や取り組みを、先 の図 4 の各項目と整合する形で整理した。白河市 における対策の特徴は、直売所や移動販売車など を除けば、幅広い事業や取り組みが実施されてい る点である。例えば、街づくりや交通対策といっ た中長期的かつ広域的なものから、配食サービス などの高歯者など対象を限定した比較的小規模の 行政サービス的な事業まで多岐にわたっている。 また、中心市街地対策や路線バスの支援の様に、 市独自による事業とともに、県や国の複数の補助 金や制度によって手厚く支援・実施されているの
も特徴である。同時に「中心市街地活性化基本計 画」等の事業は、中心市街地といった街づくり対 策だけでなく、空き店舗対策や地元商店街の支援 などの商業振興・小売対策としてメニュー的にも 利用されている（註17）。

先に指摘した様に、現在実施されている一連の 対策は食料品アクセス問題を直接の目的としたも のではなく、むしろ街づくりや交通といった既存 の制度や政策的支援の枠組みを通じて行われるの が一般的である。一方で、実際の現場の対策が多 岐にわたり、複数の事業によって重層的に構成さ れる特徵は、食料品アクセス問題が買い物という 流通や小売上の問題にとどまらずに、街づくりや 交通、あるいは高齢者問題も含んだ住民の生活環 境全般に関わる地域問題としての性格を備えてい ることを意味している。

それでは、食料品アクセス問題の解決にとって 何が重要な対策と見なされているのか。白河市で は今後重要になる対策としては、表 5 の対策項目 にマークした様に、中心市街地対策とともに大型 店・郊外店対策や路線バス等、地元商店街助成、 バス券等の外出支援、宅配・配送サービス等が選 択されており、これらは現行対策としても実施さ れている。今後重要になる対策として街づくりに 加えて、商業振興や行政サービスが重視されると いう点は住民側からも実際に支持されており、食 料品アクセス問題において地域の生活環境を重視 する点は両者ともに一致している（註18）。実際 には、これら対策を含めた直接および間接的な幅 広い対策が、市町村の現場では実施されているの である。

\section{2）現場からみた解決視点}

事例からも示された様に、食料品アクセス問題 の解決には、買い物だけでなく住民の日常的な生 活環境を維持する視点が重要となる。当然ながら、 各市町村のおかれた条件や環境によって問題の実 態は異なるものの、生活環境といった面では街づ くりや交通対策、あるいは小売や地域支援等、従 来からの事業や取り組みの強化が今後とも重要に なる。その点では、市町村といった行政部門のみ ならず事業者において、さらにはNPOや住民自 
食料品アクセス問題の実態と市町村の対応

表 5 白河市における実施対策の概要（平成22年度）

\begin{tabular}{|c|c|}
\hline 対策 & 実施根拠 \\
\hline \multicolumn{2}{|l|}{ 〈街づくり・交通対策〉 } \\
\hline & •「中心市街地活性化基本計画」(21年度～) \\
\hline & •福島県「中心市街地・商店街活性化推進事業」 \\
\hline & •福島県「福島県街なか再生特別資金融資制度」 \\
\hline \multirow{5}{*}{1 中心市街地対策の実施・支援* } & •経済産業省「戦略的中心市街地商業等活性化支援事業補助金」 \\
\hline & •経済産業省「中心市街地商業等活性化支援業務等委託事業」 \\
\hline & ·国土交通省「まちづくり交付金制度」 \\
\hline & •総務省「中心市街地再活性化特別対策事業」 \\
\hline & • 内閣府「中心市街地活性化法に基づく「中心市街地活性化基本計画」の認定制度」 \\
\hline \multirow{2}{*}{2 総合計画·都市マスタープランへの考慮·反映* } & 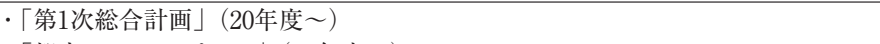 \\
\hline & ・「都市マスタープラン」(21年度〜) \\
\hline \multirow{5}{*}{$\begin{array}{l}3 \text { 大型店・郊外型店対策* } \\
4 \text { 路線バス等の運行・支援 }\end{array}$} & •福島県「福島県商業まちづくり基本方針」(18年度〜) \\
\hline & 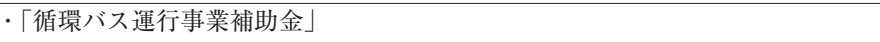 \\
\hline & •「地方バス路線維持対策事業」 \\
\hline & ·国土交通省「地域公共交通確保維持改善事業」 \\
\hline & ·福島県「福島県市町村生活交通対策事業補助金」(18年度～) \\
\hline \multicolumn{2}{|l|}{ 〈商業振興・小売対策〉 } \\
\hline 5 空き店舗対策の実施・支援 & •「中心市街地活性化基本計画（空き店舗家賃補助事業)」(21年度～) \\
\hline 6 地元商店街助成．支援* & ·「中心市街地活性化基本計画（商店街活性化事業)」(21年度～） \\
\hline & •·中企業庁「中小商業活力向上事業」 \\
\hline 7 共同・地域店舗等の出店・運営 & •「中心市街地活性化基本計画（空き店舗家賃補助事業)」(21年度～） \\
\hline 8 直売所等の出店・運営 & (未実施 $)$ \\
\hline 9 移動販売車導入 $\cdot$ 運営 $\cdot$ 支援 & " \\
\hline \multicolumn{2}{|l|}{ 〈地域づくり・支援支援〉 } \\
\hline \multirow[t]{2}{*}{10 地域の支援組織紹介・活動支援 } & •「地域づくり活性化支援事業」(20年度〜) \\
\hline & $\cdot$ \\
\hline 11 地域づくり等、地域活動の補助・支援 & • 福島県「福島県地域づくり総合支援事業 (サポート事業、県戦略事業)」(18年度〜) \\
\hline 12 高齢者・地域見守り協定等の支援 & •「単身高齢者等支援・あったか訪問事業」(21年度〜) \\
\hline \multicolumn{2}{|l|}{ 〈行政サービス〉 } \\
\hline 13 バス券等、外出支援・送迎サービス* & •「ふれあいパス事業」(21年度〜) \\
\hline 14 宅配・配送サービス等の支援 ${ }^{*}$ & •「地域づくり活性化支援事業」(20年度〜) \\
\hline 15 買い物ボランティア、代行等の紹介・支援* & •「軽度生活援助員派遣事業」（15年度～) \\
\hline 16 配食サービス等の実施・支援 & •「あったかランチお届けサービス」(22年度〜) \\
\hline
\end{tabular}

資料：筆者ら調べによる。

註：1）実施主体を記していないのは白河市によるもの。

2 ) 対策の*印は、白河市が今後重視するとした対策である。

身を含めた地域の多様な主体による連携体制の構 築が求められる。

例えば、市町村において現在実施されている食 料品アクセス問題の対策は、従来からの事業や制 度の積み上げ、すなわち各担当課の個別政策とし て分担・実施されてきた。一方で、これら対策は 現場においては事業実施のノウハウや経験が豊富 に蓄積されている。ここに、住民の買い物の不便 や苦労を軽減する視点を加えることで、より効果 的な対策の実施や運用が可能となる。また、この 様な組織間および対策間の連携は制度を効率的に 利用する契機ともなる。

事業者の視点では、食料品アクセス問題がそも そも事業環境の厳しい地域で発生していることを
考慮すれば、対策を持続可能な事業とするために は行政や地域住民の協力が不可欠となる。例えば、 事業者とのつながりや結びつきを支援することで 地域が活性化するとともに、住民の地元事業者へ のロイヤリティの向上は強力な差別化要因にもな るからである。

食料品アクセス問題は、高齢化や人口減少とい つた既にわが国全体が直面している問題の一部分 である。同時に、それらは地域の抱える個別の事 情が反映された地域問題でもある。したがって、 これらは買い物だけの問題でなく、医療や教育と いった日常生活の様々な問題に連続した地域問題 である。その意味では、食料品アクセス問題が住 民の生活環境の悪化にとどまらず、地域そのもの 
の持続可能性といった問題に発展する可能性も大 きい。その点からも、食料品アクセス問題の解決 には、多様な主体や分野での長期的かつ包括的な 取り組みが求められているのである。

（註 1 ）大店法は2000年に廃止され、以降「大規模小 売店舗立地法」が施行された。その結果、出店調 整が事実上無くなったことから、GMSの郊外出 店がさらに加速されている。また、2008年以降で は、リーマンショックによる景気後退の影響から、 GMSの突然の閉店や撤退する例もみられ、小売 環境の空白地帯が出現するなどの新たな問題も発 生している。

(註 2 ) これらの現象を商業学の視点から捉えれば、 既存の中心市街地（商店街）の商圈が縮小し、商 業活動の中心が郊外にシフトしたものとして理解 できる。

（註 3 ）徒歩での買い物が概ね $2500 \mathrm{~m}$ の範囲内にあると するのは、岩間ら [11］の先行研究に従っている。

（註 4 ）生鮮食料品販売店舗とは、果実・野菜小売業、 鮮魚小売業、食肉小売業及び食料品スーパー、総 合スーパー、百貨店のいずれかを指す。

(註 5 ) メッシュデータとは、地域を区切った区画 (メ ッシュ）単位に整備したデータであり、 $500 \mathrm{~m}$ の $1 / 2$ 基準メッシュの場合、人口の存在するメッシ ュ（居住メッシュ）は日本全国ではおよそ48万メ ッシュとなる。

（註 6 ）メッシュデータでは、各メッシュの店舗およ び住民の位置は不明である。そのため、店舗と住 民がメッシュ内に一様に分布しているとの前提で、 住民に最も近い店舗が $500 \mathrm{~m}$ 以上である確率を求 めている [12]。

（註 7 ）さらに、店舗まで $500 \mathrm{~m}$ 以上の人口割合が 100 \%のメッシュ、すなわち $500 \mathrm{~m}$ 以内に店舗が全く 存在しないメッシュは居住メッシュ全体の $65 \%$ を 占めている。

（註 8 ）これら割合は、あくまで人口をウェイトとし た加重平均であることに留意する必要がある。店 舗まで $500 \mathrm{~m}$ 以上の人口割合は市町村全体の単純 平均では $58.9 \%$ であるが、全メッシュの単純平均 は $81.7 \%$ となる $[7]$ 。

（註 9 ）店舗の定義を、コンビニ等を含む飲食料品小 売業まで拡大した食料品販売店舗では、該当する 人口は全国で 1,580 万人 (12.4\%)、65歳以上では 402万人 (15.6\%) と推計されている。

（註10）自動車保有に関しては、薬師寺・高橋［8］
註 7 参照。

（註11）本調査の翌年の2011年に実施した農林水産省 本省による全国市町村アンケートに扔いても、同 様の結果が示されている [13]。

（註12）高齢化と対策の必要性の関係には、強い相関 傾向が確認されている $[7]$ 。

（註13）都道府県によっては、市町村間の広域調整を 目指した店舗の立地規制が制度化されている。後 の事例でとりあげる福島県では、県条例によって 立地規制・誘導が行われており、全国的にも広域 的な街づくりを目指した県とされている $[14]$ 。

（註14）同時に、この検定結果により空間条件など定 量的に指標化された原因が、どの様な問題認識や 刘策といった定性的な判断・結果に結びつくかと いう、因果関係を推論することも可能である。こ れら検定の変数に人口割合を加えた主成分分析で は、集約された主成分軸に同様の傾向が確認され ている。

（註15）いわゆる「平成の合併」の結果、全国の市町 村数は3,255（1999年 3 月末）から 1,750 （2010年 3 月末）と大きく減少している。

（註16）商業統計（2007年）から推計した白河市の商 業人口（市年間販売額/県民あたり年間販売額） は66,384人であり、市人口を若干上回る。また、 図 1 に扔ける同市の生鮮食料品販売店舗まで500 $\mathrm{m}$ 以上の人口割合は $58.6 \%$ である。

（註17）白河市では、中心市街地への食料品スーパー の誘致や新たな観光・商業拠点の設置など、一定 の成果もみられている。

（註18）同時期、地方都市の中心市街地の住民を対象 に行った意識調査（n=886）では「食料品の買い 物の不便や苦労を解消するために重要なこと」(複 数回答）として「近くに店ができること」(66.2\%)、 「地元商店をもり立てること」 $(49.3 \%) 、 「$ 商品配 達サービスの充実」(13.8\%)、「バス便の改善」(7.2 \%）が上位にあげられており、何れも白河市が今 後重視する対策と一致している $[7]$ 。

\section{参考文献}

［1］杉田聡『買物難民一もうひとつの高齢者問題一』 大月書店、2008年。

[2]経済産業省『地域生活インフラを支える流通の あり方研究会報告書』2010年。

http://www.meti.go.jp/report/downloadfiles/ g100514a03j.pdf（2012年 2 月22日参照）

[3] ERS/USDA“Access to Affordable and 
Nutritious Food: Measuring and Understanding Food Deserts and Their Consequences"2009. http://www.ers.usda.gov/Publications/AP/ AP036/AP036.pdf（2012年 2 月22日参照）

[4] DEFRA “UK Food Security Assessment: Detailed Analysis"2009.

http://archive.defra.gov.uk/foodfarm/food/pdf/ food-assess100105.pdf（2012年 2 月22日参照）

［5］岩間信之『フードデザート問題』農林統計協会、 2011年。

[6 ] Glanz, K. et al "Healthy Nutrition Environment: Concepts and Measures" American Journal of Health Promotion, 2003, 19, pp.330-333.

[7]農林水産政策研究所『食料品アクセス問題の現 状と対応方向一いわゆるフードデザート問題をめ ぐって一』2012年。

http://www.maff.go.jp/primaff/koho/seika/ project/saPurail_1.html（2012年 4 月 9 日参照）

[8]薬師寺哲郎・高橋克也「食料品アクセス問題に おける店舗への近接性一店舗までの距離の計測に よる都市と農村の比較—」『フードシステム研究』 第 20 巻 1 号、2013年、pp14-25。

[9]薬師寺哲郎・高橋克也・田中耕市「住民意識か らみた食料品アクセス問題一食料品の買い物にお ける不便や苦労の要因一」『農業経済研究』第 85 巻
第 2 号、2013年（掲載予定）。

[10］薬師寺哲郎・高橋克也「食料品の買い物におけ る不便や苦労とその改善に向けての住民の意向一 大都市郊外団地、地方都市、農山村における意識 調查から一」『農村生活研究』第56巻第 2 号、2013 年 (揭載予定)。

［11］岩間信之・田中耕市・佐々木緑・駒木伸比古 · 齋藤幸生「地方都市在住高齢者の「食」を巡る生 活環境の悪化とフードデザート問題一茨城県水戸 市を事例として一」『人文地理』2009年、61（2）、 36 。

[12］薬師寺哲郎・高橋克也「生鮮食料品販売店舗へ の距離に応じた人口の推計一国勢調查と商業統計 のメッシュ統計を利用して一」『GIS一理論と応用 一』Vol.20、No.1、2012年、pp.31-37。

[13］農林水产省食料産業局『「食料品アクセス問題」 に関する全国市町村アンケート調査結果概要』 2012年。

http://www.maff.go.jp/j/shokusan/eat/syoku_ akusesu.html（2012年 7 月 2 日参照）

[14］金倉忠之「地域視点からの大型店出店問題と地 方自治体の規制手法」『人間科學研究』Vol.5、 2009年、pp.51-73。

[2012年10月18日受付、2013年 5 月13日受理］ 